\title{
COLONIAL LEGACIES IN SYRIAN NATIONALITY LAW AND THE RISK OF STATELESSNESS
}

\author{
MALAK BENSLAMA-DABDOUB*
}

The millions of Syrians born or living in exile as a result of the ongoing conflict has dramatically increased the number of people from Syria with no nationality. In this regard, Syrian nationality law has been criticised for containing discriminatory provisions and failing to address the risk of statelessness. Nonetheless, the responsibility of colonialism in creating such discrimination has been largely overlooked. One decade after the outbreak of the Syrian Civil War, this article looks back at the colonial roots of Syrian legislation governing nationality. Through a critical legal and historical analysis, it reveals the hidden colonial legacies of Syrian citizenship, by highlighting the responsibility of European colonial powers in introducing gender-based discrimination in domestic legislation, rendering Kurds and Palestinians stateless, and creating the practice of arbitrary denationalisation. This paper ends with a call for more research on colonial legacies within citizenship and statelessness studies.

\section{TABLE OF CONTENTS}

I Introduction

II Historical Context: European Colonialism and the Formation of Syria as a

Modern State

A The Dislocation of the Ottoman Empire and Creation of Artificial

Nationalities

B Syrian Citizenship Post-Independence and the Influence of Pan-Arabism

III Gender-Based Rules in Syrian Nationality law

A The Introduction of Gender-Based Discrimination by the French

Colonial Administration

B The Impact of Gender-Based Discrimination on Statelessness.

IV The Deprivation of the Right to Self-Determination for the Kurds and Palestinians

A British Support for Zionism and the Creation of Statelessness among

Palestinians

B The Legal Status of Palestinians in Syrian Nationality Law ...................... 24

C Kurdish Syrians: When Ethnic Identities Meet Stateless Identities ........... 26

V Arbitrary Denationalisation in Syrian Legislation .................................................. 29

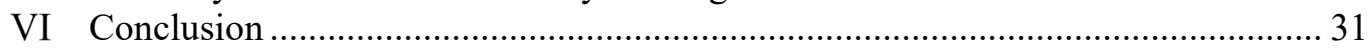

\section{INTRODUCTION}

The issue of citizenship and statelessness in Syria has been brought to the foreground by the forced displacement of nearly 13 million people since the

* $\quad \mathrm{PhD}$ Candidate at Queen Mary University of London. I am grateful to my supervisors Violeta Moreno-Lax, Nicola Piper and Shazia Choudhry for their advice and comments on earlier versions of this article. Special thanks are also due to the three anonymous peer reviewers who provided thorough feedback. My deepest gratitude goes to Bassil Dabdoub for his continuous support and encouragement. This article could not have been completed without him. 
outbreak of the civil war in $2011 .{ }^{1}$ Although political instability coupled with mass displacement of populations has dramatically increased the risk of statelessness in the country, Syrian legislation was already criticised for being discriminatory and for failing to prevent statelessness before the conflict began. Indeed, the Syrian Legislative Decree 276 ('Syrian Nationality Law') is based on the principle of paternal jus sanguinis, which means that only men can pass on their citizenship to their children. ${ }^{2}$ In the current context of the civil war, many fathers have died, disappeared or simply abandoned their children — to the point that around a quarter of Syrian refugee households are now solely led by women. ${ }^{3}$ Gender-based discrimination in Syrian nationality law has significantly increased the risk of statelessness, especially among the 1 million Syrian children born in exile. ${ }^{4}$ The civil war has furthermore exacerbated the situation of Kurds and Palestinian refugees in Syria, who are legally excluded from Syrian citizenship and naturalisation rules, and have been living in statelessness for decades. ${ }^{5}$ This situation is incompatible with many international human rights law treaties ratified by Syria, which protect the right to a nationality. ${ }^{6}$ The question of citizenship is indeed a major issue, especially for Syrians born and/or living in exile. In 2015, Syrian authorities removed major restrictions on the process of applying for and renewing Syrian passports from embassies. ${ }^{7}$ Following this decision, a record number of Syrian passport applications have been registered in embassies, which illustrates how fundamental it is for refugees to secure a passport. ${ }^{8}$ Ten years after the outbreak of the war, this paper looks back at Syrian legislation on nationality, and the resulting risks of statelessness.

1 Elizabeth Ferris, and Kemal Kirisci, The Consequences of Chaos: Syria's Humanitarian Crisis and the Failure to Protect (Brookings Institution Press 2016) 1.

2 Legislative Decree 276 'Nationality Law' (1969) art 3 (Syrian Arab Republic) $<$ https://www.refworld.org/pdfid/4d81e7b12.pdf> ('Syrian Nationality Law').

3 Woman Alone: The Fight for Survival by Syria's Refugee Women (Report, UNHCR 2 July 2014) <https://www.refworld.org/docid/53be84aa4.html > ('Woman Alone').

4 'Syria Refugee Crisis Explained' (n 1); Charlie Dunmore, 'Born in Exile, Syrian Children Face Threat of Statelessness', UNHCR (Web Page, 4 November 2014) $<$ https://www.unhcr.org/uk/news/latest/2014/11/54589fb16/born-exile-syrian-children-facethreat-statelessness.html>.

5 Thomas McGee, From Syria to Europe: Experiences of Stateless Kurds and Palestinian Refugees from Syria Seeking Protection in Europe (Report, Institute of Statelessness and Inclusion 2019).

6 See, eg, Universal Declaration of Human Rights, GA Res 217A (III), UN GAOR, 3rd sess, 183rd plen mtg, UN Doc A/810 (10 December 1948) art 15 ('UDHR'); International Covenant on Civil and Political Rights, opened for signature 16 December 1966, 999 UNTS 171 (entered into force 23 March 1976) art 24(3) ('ICCPR').

7 Previously, Syrians who had left the country 'illegally' had to go through an 'intelligence service review' in order to obtain a Syrian passport. Relevant Country of Origin Information to Assist with the Application of UNHCR's Country Guidance on Syria: 'Illegal Exit' from Syria and Related Issues for Determining the International Protection Needs of AsylumSeekers from Syria (Report, UNHCR February 2017).

8 'Syria Government Profits from Hike in Passport Demand', Middle East Eye (online, 26 October 2015) <http://bit.ly/2k39x7C>; 800.000 Neue Pässe 'Ausgegeben: Syriens Regime Verdient Gut an Flüchtlingen', Der Tagesspiegel (online, 5 November 2015) $<$ http://bit.ly/2aFbeot $>$. 
Although the current academic literature has clearly identified and criticised the flaws and discrimination in Syrian nationality law, ${ }^{9}$ the impact of colonialism in creating such discrimination has been largely neglected. Yet, Syrian legislation on nationality - as we know it today - has been directly influenced by colonialism and imperialism. ${ }^{10}$ French colonisation of Syria, which lasted from 1922 to $1946,{ }^{11}$ played a pivotal role in the development of Syrian citizenship. Nonetheless, the academic literature on this topic is relatively scarce partially because France refused to open its colonial archives until $1987 .{ }^{12}$ Moreover, the Western academic scholarship on Syrian citizenship fails to take into consideration colonial legacies. This article fills this research gap by exploring the role of colonialism calls in shaping Syrian nationality laws and creating risks of statelessness. In doing so, it builds upon postcolonial scholarship and third world approaches to international law ('TWAIL'). Through an anti-colonial analysis, this paper proceeds with a historico-legal analysis of Syrian citizenship rules and current situations of statelessness.

Before French colonisation formally began in 1922, Syria lived under Ottoman rule for more than four centuries. ${ }^{13}$ During World War I, the Allies needed the support of Arabic-speaking populations in order to defeat the Ottomans. Thereafter, Britain promised Arab leaders the creation of a sovereign and independent 'Arab State', in exchange of their military and political support against the Ottomans. ${ }^{14}$ Arab leaders, who were looking to end four centuries of Ottoman occupation, accepted and fought alongside the Allies during World War

9 Zahra Albarazi, The Stateless Syrians (Report No 11/2013, Tilburg University 2013) ('The Stateless Syrians'); David M Howard, 'Analyzing the Causes of Statelessness in Syrian Refugee Children' (2017) 52(1) Texas International Law Journal 221; Submission to the Human Rights Council at the 26th Session of the Universal Periodic Review (Report, Institute on Statelessness and Inclusion and The Global Campaign for Equal Nationality Rights 24 March 2016) <https://equalnationalityrights.org/images/zdocs/ISI-GCENR---UPRSubmission-Syria---March-2016-Final.pdf $>$.

10 Elizabeth F Thompson, Colonial Citizens: Republican Rights, Paternal Privilege, and Gender in French Syria and Lebanon (Columbia University Press 2000); The Stateless Syrians (n 9).

11 Daniel Neep, Occupying Syria under the French Mandate (Cambridge University Press 2012) 3.

12 Peter A Shambrook, French Imperialism in Syria, 1927-1936 (Ithaca Press 1998) preface.

13 Ma'oz, Moshe, Yosef Ginat and Onn Winckler, Modern Syria: From Ottoman Rule to Pivotal Role in the Middle East (Sussex Academic Press, 1999); James L Gelvin, Divided Loyalties: Nationalism and Mass Politics in Syria at the Close of Empire (University of California Press, 1998). The Ottoman Empire ruled over Syria from 1516 to 1918. The period is referred to as the Ottoman 'occupation' and not 'colonisation' for a series of reasons. Firstly, major European colonial powers (such as Britain, France, Spain and Portugal) organised large-scale migrations by sending colonial settlers in their overseas territories. For instance, more than 1.6 million French citizens were living in Algeria before the country obtained independence. On the other hand, the Ottomans were not looking to 'replace' native populations. Secondly, behind European colonisation lies a discourse and policies of racial hierarchy and civilisation claims. European conquests justified their brutal rule and occupation on the basis that they had a duty to bring enlightenment to 'the barbarians'. On the other hand, the Ottomans did not reproduce such 'civilising discourse' and recognised that that their conquests were solely motivated by economic/military ambitions. Thirdly, Ottoman rule was not an alien nonconsensual rule. The Ottomans did not try to impose their language and customs, did not seek to divide local populations and left a relative political autonomy to regions of the empire. Fourthly, European colonial powers forcibly enforced cultural conversions, language spread and religious change. A contrario, the Turks were not looking to impose any cultural or linguistic change. Finally, the Ottomans conquered and occupied territories that were adjacent to their homelands, in an effort to 'expand' their territory. Conversely, European colonial powers established settlements in lands scattered all over the world, including in America, Africa, Asia and Australia.

14 Correspondence between Henry McMahon and Hussein ibn Ali, July 1915 - March 1916. 
I. ${ }^{15}$ After the defeat of the Ottoman Empire, the Syrian National Congress issued a declaration of independence on 8 March 1920, creating the sovereign State of 'Bidal al-Sham' or 'Greater Syria'. This State was a democratic parliamentary monarchy, which covered the current territories of Lebanon, Syria, Jordan, Palestine and Israel. ${ }^{16}$ The 1920 Constitution of the Syrian Arab Kingdom instituted a separation of powers, established a legislative control of the monarch's prerogatives, removed Islam as the State religion, and granted equal rights to all citizens regardless of their ethnicity or religious beliefs. ${ }^{17}$ Unfortunately, the Allies refused to keep their initial promise and chose, instead, to colonise the Arab provinces of the Ottoman Empire. ${ }^{18}$ Britain and France were looking to pursue their colonial, political and economic aspirations - and had no desire to uphold Syrians' aspirations for self-government and independence. Britain was looking to safeguard the route to India and secure oil for the navy, while France wanted to secure cheap supply of cotton and silk. ${ }^{19}$ In July 1920, British and French military troops forced political leaders into exile. ${ }^{20}$ In order to contain nationalist movements and reinforce their domination, the Anglo-French alliance cut down the Arab provinces and drew artificial borders in the secret 1916 Sykes-Picot Agreement negotiations ('Sykes-Picot Agreements'), without any consideration for the local population. ${ }^{21}$ Britain seized power over Mesopotamia, the Gulf and Palestine, whilst France took control over the Levant (ie Syria and Lebanon). ${ }^{22}$ This colonial mapping was motivated by divide-and-rule policy, a political strategy whereby a dominant power maintains control over a land by dividing its people, thereby preventing from uniting in opposition. ${ }^{23}$ This colonial enterprise created a mismatch between identity and nationality that is partially responsible for the current plight of statelessness in Syria - and largely, in the Middle East.

15 Trevor J Le Gassick, 'Studies in Contemporary Arab Nationalist Literature' (DPhil thesis, SOAS University 2015) 6.

16 Elizabeth F Thompson, How the West Stole Democracy from the Arabs (Grove Press 2020) xi.

17 Yusuf Mazin, The Syrian Congress: the Independent Parliament of Greater Syria (Dar alSharq 2011), citing the Constitution of the Syrian Arab kingdom 1920 (no longer in force); Elizabeth F Thompson 'Rashid Rida and the 1920 Syrian-Arab Constitution: How the French Mandate Undermined Islamic liberalism' in Cyrus Schayegh and Andrew Arsan (eds), The Routledge Handbook of the History of the Middle East Mandate (Routledge 2015) 244.

18 Ernest C Dawn, 'From Ottomanism to Arabism: The Origin of an Ideology' (1961) 23(3) The Review of Politics 378; Zeine N Zeine, Arab-Turkish Relations and the Emergence of Arab Nationalism (Khayat's, 1958) 58. See also Rashid Khalidi et al (eds) The Origins of Arab Nationalism (Columbia University Press 1991).

19 Shambrook (n 12) 1. See also Gibbons Herbert Adams, The Defects of the System of Mandates (1921) 96(1) Annals of the American Academy of Political and Social Science 84; Ayse Tekdal Fildis, 'The Troubles in Syria: Spawned by French Divide and Rule' (2011) 18(4) Middle East Policy 129.

20 Gassick (n 15) 4-5; Reem Abou-El-Fadi, 'Early Pan-Arabism in Egypt's July Revolution: The Free Officers Political Formation and Policy-making, 1946-54' (DPhil thesis, SOAS University 2015) 289; Thompson (n 10) xv.

21 James Barr, A Line In The Sand: Britain, France and the Struggle that Shaped The Middle East (Simon and Schuster, 2011) 6-12.

22 This division was formalised in the secret Sykes-Picot Agreement (entered into force 3 January 1916). See Meir Zamir, The Secret Anglo-French War in the Middle East: Intelligence and Decolonization, 1940-1948 (Routledge 2014) 8.

23 See Richard Morrock, "Heritage of Strife: The Effects of Colonialist "Divide and Rule" Strategy upon the Colonized Peoples' (1973) 37(2) Science \& Society 129; Nic Cheeseman, Eloïse Bertrand, and Sa'eed Husaini 'Divide and Rule' in A Dictionary of African Politics (Oxford University Press 2019). 
Yet, international law on statelessness and citizenship utterly overlooks the importance of (de)colonial legacies. ${ }^{24}$ Both the 1954 Convention Relating to the Status of Stateless Persons and the 1961 Convention on the Reduction of Statelessness ('Statelessness Conventions') are based on the premises that statelessness is principally due to a conflict of nationality laws, arbitrary deprivation of nationality or gender-based discrimination, but disregard the largescale impact of colonialism in creating statelessness. ${ }^{25}$ In this regard, TWAIL offer a valuable standpoint in deconstructing the colonial features and effects of international law. ${ }^{26}$ Through a critical legal analysis, TWAIL scholars seek to challenge the supposedly 'universality' of international law and demonstrate how the international legal framework perpetuate unequal power relations. Notably, TWAIL scholarship questions the premises that international human rights law instruments are emancipatory. Rather, they emerge as Eurocentric projects, exclusively drafted by wealthy powerful nations, in an attempt to reinforce the dominance of the 'Global North' over the 'Global South', and the subordination of non-Europeans to Europeans. ${ }^{27}$ In doing so, TWAIL scholars notably rely on a critical historical perspective on the foundations of international law.

Against this background, this article aims at filling the existing research gap by exploring Syrian nationality legislation and statelessness through an anti-colonial perspective. This paper builds upon TWAIL scholarship in an effort to deconstruct and uncover the hidden colonial features of Syrian citizenship. Ultimately, this paper argues that discriminatory provisions in Syrian nationality laws and the resulting risk of statelessness bear the legacies of European colonialism and hegemony. This analysis starts first by offering a historical context on the colonial history and formation of Syria as a modern nation-State. The following Part exposes the colonial responsibility in introducing gender-based discrimination in Syrian citizenship, and in depriving the Kurds and Palestinians from their right to self-determination. Part V explores arbitrary deprivation of nationality in Syria as an act inspired by European practices. Finally, this paper ends with concluding thoughts, summarising the main findings and calling for the value of an anticolonial analysis of citizenship.

24 Malak Benslama-Dabdoub, 'Decolonising Statelessness: Unpacking Colonial Legacies and Deconstructing Forms of Epistemic Violence', CSS Blog, University of Melbourne (Blog Post, January 2021) <https://law.unimelb.edu.au/centres/statelessness/critical-statelessnessstudies-blog/decolonising-statelessness-unpacking-colonial-legacies-and-deconstructingforms-of-epistemic-violence>.

25 See Convention Relating to the Status of Stateless Persons, opened for signature 28 September 1954, 360 UNTS 117 (entered into force 6 June 1960); Convention on the Reduction of Statelessness, opened for signature 30 August 1961, 989 UNTS 185 (entered into force 13 December 1975).

26 James Thuo Gathii, 'Rejoinder: TWAILing International Law' (1999) 98(6) Michigan Law Review 2066; Makau Mutua and Antony Anghie, 'What is TWAIL?' [2000] 94 Proceedings of the Annual Meeting (The American Society of International Law) 31; Obiora Chinedu Okafor, 'Critical Third World Approaches to International Law (TWAIL): Theory, Methodology, or Both?' (2008) 10(4) International Community Law Review 371; Luis Eslava and Sundhya Pahuja, 'Between Resistance and Reform: TWAIL and the Universality of International Law' (2011) 3(1) Trade, Law and Development 103; Luis Eslava and Sundhya Pahuja, 'Beyond the (Post) Colonial: TWAIL and the Everyday Life of International Law' (2012) 45(2) Verfassung und Recht in Übersee/Law and Politics in Africa, Asia and Latin America 195.

27 Ratna Kapur, Gender, Alterity and Human Rights: Freedom in a Fishbowl (Edward Elgar Publishing 2018). 
II Historical Context: European COLONIALiSM AND THE Formation OF

SYRIA AS A MODERN STATE

\section{A The Dislocation of the Ottoman Empire and Creation of Artificial}

\section{Nationalities}

In order to understand the current rules governing Syrian citizenship, it is necessary to trace back the historical formation of Syria as a nation-state. After the fall of the Ottoman Empire, Britain and France instituted a system of 'Mandates' in order to maintain their control over the Fertile Crescent. ${ }^{28}$ Under this system, which was approved by the League of Nations, 'Mandatory' powers were in charge of 'assisting' native peoples who were 'not able to stand by themselves under the strenuous conditions of the modern world' ${ }^{29}$ The Allies deemed that this system of tutelage was the appropriate solution for what they regarded as 'politically backward people' incapable of governing themselves. ${ }^{30}$ The occupation of Syria was based on a colonial organisation and imperial discourse that saw native populations in the Middle East as inferior, uncivilised and incapable of administrating themselves. The former French Prime Minister Alexandre Millerand declared in 1919 that France had 'a sacred duty' to help Syrians 'realise their legitimate aspirations' and 'organise themselves as nations'. ${ }^{31}$ Yet, when the Syrian people issued a declaration of independence in 1920, and created a sovereign State based on principles of democracy and equality, the Anglo-French Alliance forcibly crushed them down, and forced their political leaders to exile. By doing this, Elizabeth F Thompson claims that 'Europeans stole Arab democracy and expelled Syria from the so-called civilised world'. ${ }^{32}$ As a result, the paternalist discourse that sought to justify European occupation, on the basis of a duty to so-called 'assist' native populations in 'governing themselves' was a fallacy aimed at disguising colonialism.

Although the League of Nations expressly stated in its declaration that the Mandatory power shall 'encourage local autonomy' and 'take into account the rights, interests and wishes of the population', ${ }^{33}$ France treated its possessions in the Levant as part of its colonial empire. ${ }^{34}$ The brutality of French colonial rule in Syria proved that France never sought to bring autonomy to native populations. In fact, France took de facto control over Syria in 1918-19, but the League of Nations established the Mandates System only three years later. Therefore, the System of Mandates provided a legal formula for colonisation and the League of Nations had

28 This division was agreed during the Anglo-French Conference of San Remo, in April 1920. See David Kenneth Fieldhouse, Western Imperialism in the Middle East 1914-1958 (Oxford University Press 2006) 36-41.

29 Treaty of Peace between the Allied and Associated Powers and Germany, signed 28 June 19191, 225 ConTS 188 (entered into force 10 January 1920) art 22(1) ('Covenant of the League of Nations').

30 Quincy Wright, 'The United States and the Mandates' (1925) 23(7) Michigan Law Review 722.

31 Safiuddin Joarder, Syria under the French Mandate: The Early Phase 1920-1927 (Asiatic Society of Bangladesh Publications, 1977) iv.

32 Thompson, How the West Stole Democracy (n 16) xiii.

33 'Annex 391a: French Mandate for Syria and the Lebanon' (1922) 3(8) League of Nations Official Journal 1013, 1013-17.

34 Joarder (n 31) iv. 
no say over France's presence in Syria. ${ }^{35}$ According to the Syrian nationalist leader Shakib Arslan:

It should be clearly understood that the League of Nations, from the Syrian point of view, is simply an institution whose aim is to provide a clock of legality for the greedy encroachments of France and England. ${ }^{36}$

For the first time, Syrians experienced how international law upholds and reinforces imperial ambitions by sanitising colonial language. In this regard, the League of Nations provided a prelude to the United Nations' mechanisms to serve imperial ambitions and reinforce inequality among states. This is what Erakat refers to as 'the sordid origin of international law as a derivative of a colonial order' ${ }^{37}$ In effect, the idea that the Mandates System somehow benefited local populations is contradicted by historical evidence which illustrates the violence of French colonial rule in Syria. The French Mandatory power exercised a unilateral rule that left no autonomy to Syrians. France started first by institutionalising a framework that enabled the colonial administration to enact legislation without consulting the Syrian population. Rather than recognising the purely economic and political motivations behind colonialism, France justified its colonial conquests by advancing the duty of mission 'civilisatrice' — the 'civilising' mission. According to this notion, Europeans had a 'moral duty' to 'civilise' indigenous people by occupying them and expropriating their resources. ${ }^{38}$ To quote the words of the French Prime Minister in 1885, 'the superior races ... have the duty to civilize the inferior races' ${ }^{39}$ In 1920, a French statesman addressed the Parliament about the Mandate over Syria and declared: 'we have the duty to stay there and bring autonomy to these people we taught liberty to and whom, without us, might fall back into the despotism of fanaticism'. ${ }^{40}$ French authorities fabricated a false narrative of Arab extremism and Islamic fanaticism, and how the occupation of Syria was the only solution to counter such threat to peace. ${ }^{41}$

In reality, French colonial occupation brought land exploitation and tyranny not freedom and autonomy. Today, the vast majority of historians reject the fallacy that French rule in Syria - and colonialism in general - aimed at advancing the rule of law and was emancipatory. ${ }^{42}$ Philip S Khoury argues that France carried

35 Shambrook (n 12) 2.

36 Joarder (n 31) iii.

37 Noura Erakat, Justice for Some: Law and the Question of Palestine (Stanford University Press 2019) 6.

38 Mathew Burrows, "Mission Civilisatrice": French Cultural Policy in the Middle East 18601914' (1986) 29(1) The Historical Journal 112.

39 Jules Ferry, 'Speech before the French Chamber of Deputies' (Speech, Paris, 28 March 1884).

40 Journal officiel de la République française: Débats parlementaires. Chambre des députés : compte rendu in-extenso (Archived Debate, 26 June 1920) 2464 $<$ https://gallica.bnf.fr/ark:/12148/bpt6k6331074c/f2.item> (tr author). The French original version is:

nous nous devons de rester là-bas et ... amener normalement à l'autonomie ces peuples que nous avons éveillés a la liberté et qui, sans nous, risquent de retomber sous le despotisme du fanatisme.

41 Thompson, How the West Stole Democracy (n 16) xvi.

42 Munir Al-Rayyis, The Golden Book of Nationalist Revolutions in the Arab East [كتاب الذهبي [للتورات الوطنية في المشرق العربي (Dar al-Tali‘a li-al-Taba‘a wa al-Nashr, 1969) vol 1, 142; Andrew and Kanya-Forstner, 'The Climax of French Imperial Expansion 1914-1924' (Stanford University Press 1981) 14-21; Aimé Césaire, Discourse on Colonialism (New York University Press 2000) 32; Joarder (n 31) 73. 
out 'a dictatorial policy' in Syria, ${ }^{43}$ and James Barr describes French rule in the Levant as 'arbitrary, confessional, exploitative and corrupt'. ${ }^{44}$ The colonial administration enacted sectarian policies to reinforce its domination and power. France applied the 'divide-and-rule' policy in all its colonies, ${ }^{45}$ including Syria, and broke down national unity by conducting a policy of sectarian division, ${ }^{46}$ ethnic segregation ${ }^{47}$ and regional separatism ${ }^{48}$ in order to maintain its influence. ${ }^{49}$ Notably, it did so by creating the State of Lebanon in 1920 and by fragmenting Syrian territories into religious and ethnic communities. ${ }^{50}$ This politics was part of a colonial effort to racialise religious and ethnic communities. ${ }^{51}$ For instance, the Alawite and the Druze ethnic minorities were administrated separately from the rest of the Syrian people. ${ }^{52}$ These politics of division had a damaging impact on the Levant and left long-lasting marks that can still be felt to this day. ${ }^{53}$ The outbreak of the 15-year civil war in Lebanon, and the rise of sectarianism in Syria is partially attributed to the strategy of division enacted by the French during the occupation. ${ }^{54}$ Overall, this political of division enacted by both France and Britain in the Middle East has created a mismatch between identity and nationality.

Inevitably, this brutal colonial rule engendered resistance from the Syrian people. Peaceful anti-colonial protests took place at the beginning of the occupation, to which France responded with massive executions, forced exile and military operations. ${ }^{55}$ In the summer of 1925 , an armed revolt broke down in the Druze Mountains of Syria, and later spread to the rest of the region. ${ }^{56}$ This uprising was described as 'the largest [and] longest' uprising that the Arab Middle East had ever seen before. ${ }^{57}$ France violently repressed this revolt by bombing Damascus for 24 hours, killing thousands of civilians and leaving the ancient city in ruins. ${ }^{58}$ The Syrian people finally managed to achieve independence after the end of World War II. The last French soldier in Syria was expelled on 17 April 1946: this is annually commemorated by Syrians as their 'Independence Day'. 59

43 Philip S Khoury, Syria and the French Mandate: The Politics of Arab Nationalism, 19201945 (Princeton University Press 2014) 5.

44 Barr (n 21) 2.

45 Richard Morrock, 'Heritage of Strife: The Effects of Colonialist "Divide and Rule" Strategy upon the Colonized Peoples' (1973) 37(2) Science and Society 129; 'Divide and Rule' in Nic Cheeseman, Eloïse Bertrand, and Sa'eed Husaini (eds), A Dictionary of African Politics (Oxford University Press 2019).

46 Ussama Makdisi, Age of Coexistence: The Ecumenical Frame and the Making of the Modern Arab World (University of California Press 2019) 3-4.

47 Al-Rayyis (n 42) 112-31.

48 Neep (n 11) 31.

49 Khoury, Syria and the French Mandate (n 43) 11.

50 Phillip S Khoury, 'Syrian Urban Politics in Transition: The Quarters of Damascus During the French Mandate' (1994) 16(4) International Journal of Middle East Studies 507, 508.

51 Michael Fakhri, 'Introduction: Questioning TWAIL's Agenda' (2012) 14(1) Oregon Review of International Law 1.

52 Fildis (n 20).

53 Khoury, Syria and the French Mandate (n 43) 58.

54 Christian Velud, 'Le mandat Français' in Anne Marie Bianquis (ed), Damas: miroir brisé d'un Orient arabe (Autrement 1993) 87.

55 ibid 196.

56 ibid 199.

57 Michael Provence, The Great Syrian Revolt and the Rise of Arab Nationalism (University of Texas Press 2005) 12.

58 ibid.

59 Mouhmad Al-Hassan, 'The French Mandate in Syria' (DPhil thesis, University of Damascus 1986) 32 . 
It is the same politic of division that justified the creation of artificial borders by the Anglo-French alliance in the secret Sykes-Picot Agreements. France created the State of Lebanon in Syria ${ }^{60}$ and Britain divided Mesopotamia into the new states of Iraq and Jordan. ${ }^{61}$ Native populations disagreed with the new borders set up by European colonial powers. For instance, the decision to annex the Iskenderun Syrian district to the new State of Turkey, despite the fact that this region was populated by a vast majority of Arabs who spoke the Syrian dialect, was strongly contested. ${ }^{62}$ The creation and separation of Lebanon from Syria was, likewise, contested by native populations. ${ }^{63}$ Moreover, Britain promised to create 'a Jewish home' in Palestine in the Balfour Declaration, ${ }^{64}$ paving the way for the mass displacement of millions of Palestinians and the current Israeli-Palestinian conflict. ${ }^{65}$ The Kurdish people were initially promised a State in the Treaty of Sèvres ${ }^{66}$ but were later stripped of their right to self-determination ${ }^{67}$ after renegotiations with Turkey in the Treaty of Lausanne. ${ }^{68}$ As a result of this decision, the Kurds have been left without a state and form today the largest nation without a country in the world. ${ }^{69}$

The dislocation of the former Ottoman Empire had a direct impact on citizenries that explain current nationality rules in the Middle East. With the creation of new states naturally came the necessity to determine which citizens belonged to each State. ${ }^{70}$ European colonial powers established the new nationality rules that would apply after the dissolution of the Ottoman Empire in art 30 of the Treaty of Lausanne, according to which:

Turkish subjects habitually resident in territory which in accordance with the provisions of the present Treaty is detached from Turkey will become ... nationals of the State to which such territory is transferred. ${ }^{71}$

60 Lebanon - as we know it today — was not a state before France created it in 1923. See Fildis (n 20) 133.

61 Barr (n 21).

62 Haitham Manaa, Stateless Persons in Syria (Report, Arab Commission on Human Rights 2004) <http://hem.bredband.net/dccls2/r1.htm>.

63 Khoury, Syria and the French Mandate (n 43).

64 Imperial Conference 1926 (Report No E(IR/26), Inter-Imperial Relations Committee 1926).

65 Gardner Thompson, Legacy of Empire: Britain's Support of Zionism and the Creation of Israel (Saqi Books 2019) 4.

66 Treaty of Peace Between the Allied and Associated Powers and Turkey, signed 10 August 1920) ('Treaty of Sèvres'). Kurdistan was an independent state before the Ottoman invasion in the $15^{\text {th }}$ century. See Philip G Kreyenbroek and Stefan Sperl, The Kurds: A Contemporary Overview (Routledge 2005) 12.

67 Although the right of 'self-determination' was not part of international law until it was introduced in the $U D H R$ (n 6) in 1948, this legal concept can be found in earlier speeches and declarations. Notably, former President of the United States Woodrow Wilson was a driving force behind the adoption of the right to self-determination in several treaties, including the Covenant of the League of Nations. See Antony Anghie, 'Colonialism and the Birth of International Institutions: Sovereignty, Economy, and the Mandate System of the League of Nations' (2002) 34(3) New York University Journal of International Law and Politics 513; Trygve Throntveit, 'The Fable of the Fourteen Points: Woodrow Wilson and National SelfDetermination' (2011) 35(3) Diplomatic History 445.

68 Treaty of Peace with Turkey Signed at Lausanne, signed 24 July 1923 (entered into force 6 August 1924) ('Treaty of Lausanne').

69 Bekir Halhalli, 'Kurdish Political Parties in Syria: Past Struggles and Future Expectations' in Emel Elif Tugdar and Al Serhun (eds), Comparative Kurdish Politics in the Middle East (Palgrave Macmillan 2018) 27-53.

70 Laura van Waas, The Situation of Stateless Persons in the Middle East and North Africa (Report, UNHCR 2010) 6.

71 Treaty of Lausanne (n 68) art 30. 
Accordingly, European colonial powers linked nationality to residency, without any regard to the lineage, ethnic identity or the place of birth of the individuals concerned. The creation by European colonial powers of the concept of 'nationstates' in itself only aimed at reinforcing imperial dominance rather than benefiting local populations. ${ }^{72}$ Article 30 of the Treaty of Lausanne was implemented in all former provinces of the Ottoman Empire. In Syria, the French Mandate issued an arrêté ${ }^{73}$ that established the following golden rule: any inhabitant in Syrian territory was to be considered Syrian, except if they explicitly renounced their nationality. ${ }^{74}$ This was an artificial artefact because residency does not necessarily coincide with identity. Many populations displaced during the Ottoman Empire or after its fall, who sought refuge in Syria, had no ancestral link to the Syrian territory. ${ }^{75}$ The creation of artificial borders by colonial powers inevitably resulted in the creation of artificial nationalities. European jurists describe nationality as 'the effective link', ${ }^{76}$ 'the genuine connection' ${ }^{\text {'77 }}$ and ' $u n$ attachement réel' - 'a real connection' - between the individual and the State. ${ }^{78}$ It raises the question of whether nationality rules in the Middle East — and former colonised countries in general - can be considered 'real' or 'genuine', since they are the result of arbitrary colonial mapping.

\section{B Syrian Citizenship Post-Independence and the Influence of Pan-Arabism}

After the end of French colonial rule, Syrian citizenship went through three different stages. The first nationality legislation passed by independent Syria was the Law No 98 of 12 May 1951, later replaced by the Law No 21 of February $1951 .{ }^{79}$ Citizenship rules were then modified by the Law No 82 of July 1958, after Syria joined the United Arab Republic. It was later abolished by Law No 67 of October 1961 after Syria left the union. Finally, Syrian nationality law went through a last modification in 1969, following the accession in power of the Baa'th party. This legislation still regulates Syrian citizenship to this day. Article 48 of the current Constitution of the Syrian Arab Republic states that nationality is regulated by a legislative act. As such, modifications in nationality rules do not require constitutional amendment. This sub-section critically engages with the evolution of Syrian citizenship post-independence through an anti-colonial lens.

As mentioned in the introduction, the Anglo-French Alliance initially promised Arab populations the creation of an independent state in exchange for their

72 Albert Memni, The Colonizer and the Colonized (Earthscan Publications 1957).

73 It literally means 'unilateral administrative act' but can be translated as 'decree' in English.

74 Arrêté No 2825 et No 2825 bis du 30 août 1924 [Decree No 2825 and No 2825 bis of 30 August 1924] (French Administration in Syria), republished in League of Nations, Report by the Representative of New Zealand on the Work of the Twenty-Eighth Session of the Health Committee, LN Doc C.258.1938.III (13 August 1938) $75<$ https://biblioarchive.unog.ch/Dateien/CouncilDocs/C-258-1938-III_EN.pdf>.

75 Fildis (n 20) 89. See also Isa Blumi, Ottoman Refugees, 1878-1939: Migration in a PostImperial World (A\&C Black 2013).

76 International Law Commission, 'Draft Articles on Nationality of Natural Persons in Relation to the Succession of States with Commentaries' (1999) 2(2) Yearbook of the International Law Commission 23, 39 art 19.

77 Nottebohm Case (Liechtenstein v Guatemala) (Second Phase) (Judgment) [1955] ICJ Rep 4, 24.

78 José Francisco Rezek, Le droit international de la nationalité (Recueil des cours 1986) 357.

79 Law No 98 of 12 May 1951 (Syrian Arab Republic) (no longer in force), replaced by Law No 21 of February 1951 (Syrian Arab Republic), cited in Uri Davis, 'Citizenship Legislation in the Syrian Arab Republic' (1996) 18(1) Arab Studies Quarterly (1996) 29, 34. 
political and military support against the Ottomans. ${ }^{80}$ But after defeating the Ottomans, colonial powers did not keep their promise and crushed all political inspirations for Arab unity. ${ }^{81}$ Native populations were divided into artificial nation-states in order to contain nationalism and anti-colonial movements. ${ }^{82}$ After decolonisation, nationalists called for a reunification of all Arab states to overcome the divisions enacted during colonial rule. In this context, Pan-Arabism rose as a significantly strong and credible anti-colonial ideal. This project, also referred to as 'Arab nationalism', can be defined as a transnational and secular movement that advocates for the reunification of all Arab territories. ${ }^{83}$ Although the origins of this movement can be traced back to the Ottoman Empire, ${ }^{84}$ it emerged as a massive and popular ideology after World War I, both as an attempt to resist colonial rule and the creation of artificial borders by European powers. Arab nationalists advocate for the creation of a united Arab state, drawing on the historical example of the $12^{\text {th }}$ century Arab Empire. ${ }^{85}$

Pan-Arabism was formalised in different political projects, ${ }^{86}$ such as Nasserism in Egypt and Baathism in Iraq and Syria. ${ }^{87}$ Egypt and Syria managed to achieve this inspiration for Arab unity through the creation of a unified sovereign Arab state in 1946, called the United Arab Republic ('UAR'). ${ }^{88}$ Yemen later signed a pact with the UAR in 1948 to be connected with a federation called the 'United Arab States' but without fully joining the union. ${ }^{89}$ During this period, all Syrians were considered nationals of the UAR. ${ }^{90}$ However, this union collapsed few years after, in 1961, following a coup d'état in Damascus. ${ }^{91}$ Although the creation of a unified Arab nation has not succeeded, Pan-Arabism has been translated in other forms of expressions, including intergovernmental cooperation between sovereign states. The most successful example of this expression is the League of Arab States ('LAS'), ${ }^{92}$ a regional organisation framed around a common Arab identity and affinity. Within the past few decades, the definition of Pan-Arabism evolved, and is now broadly understood as 'an idea and a movement that recognises the close affinity shared by the Arab people and attempts to give that affinity some

80 Trevor J Le Gassick, 'Studies in Contemporary Arab Nationalist Literature' (DPhil thesis, SOAS University 2015) 6.

81 Ernest C Dawn, 'From Ottomanism to Arabism: The Origin of an Ideology' (1961) 23(3) Review of Politics 378; Zeine N Zeine, Arab-Turkish Relations and the Emergence of Arab Nationalism (Khayat's, 1958) 58. See also Rashid Khalidi et al (eds), The Origins of Arab Nationalism (Columbia University Press 1991).

82 Gassick (n 80) 4-5; Reem Abou-El-Fadi, 'Early Pan-Arabism in Egypt's July Revolution: The Free Officers Political Formation and Policy-Making, 1946-54' (DPhil thesis, SOAS University 2015) 289.

83 Barry Rubin, 'Pan-Arab Nationalism: The Ideological Dream as Compelling Force' (1991) 26(3) Journal of Contemporary History 535.

84 Zeine (n 81) 58; Khalidi et al (n 81).

85 Gassick (n 80) 6.

86 Thompson, Colonial Citizens (n 10) 41.

87 Raymond A Hinnebusch, 'Syria's Alawis and the Ba'ath Party' in Michael Kerr and Craig Larkin (eds), The Alawis of Syria: War, Faith and Politics in the Levant (Oxford University Publishing 2015) 108.

88 Raymond A Hinnebusch, Authoritarian Power and State Formation in Ba 'thist Syria: Army, Party, and Peasant (Westview Press 1990) 110.

89 Eugene Cotran, 'Some Legal Aspects of the Formation of the United Arab Republic and the United Arab States' (1959) 8(2) The International and Comparative Law Quarterly 346.

90 Davis (n 79).

91 Khoury, Syria and the French Mandate (n 43) 121.

92 Also known as 'the Arab League'. 
meaningful practical expression'. ${ }^{93}$ This broader understanding of Pan-Arabism does not assert that all Arab states should unify into one nation, but rather advocates for cooperation on the basis of this shared 'Arab identity'. Whilst there are still ongoing debates about what this common identity rests upon, it emerges as a strong anti-colonial movement to rectify politics of division enacted during colonisation.

Following the collapse of the UAR, Syria went through a period of political instability, with a succession of coups d'états and temporary governments that did not last more than five years. ${ }^{94}$ This ended in 1963, when the Ba'ath party seized power in a military coup d'état, and has been ruling the country ever since. ${ }^{95}$ Ba'athism is a political movement that calls for the unification of all Arab territories into one single state, and advocates for the end of foreign interference. ${ }^{96}$ The Pan-Arabist ideology of the Ba'ath party is strongly reflected in the current Syrian political and legal framework. According to the Constitution of the Syrian Arab Republic, ${ }^{97}$ the official name of the country is 'Syrian Arab Republic', described as 'part of the Arab homeland' and the Syrian people are considered 'part of the Arab nation' with an 'Arab identity'. ${ }^{98}$ Likewise, the preamble of the previous Syrian constitution, before it was amended in 2012, directly refers to the 'colonial conquests [that] shattered the Arab nation's unity, occupied its territory, and plundered its resources'. ${ }^{99}$ The historical and political significance of PanArabism is also reflected in the current Syrian citizenship rules. Article 4(1)(f) of Syrian Nationality Law sets out the conditions for Syrian naturalisation as follows: (i) a five-year legal residency requirement; (ii) having full legal capacity; (iii) meeting certain medical conditions; (iv) having 'good character'; (v) having legitimate means to earn a living; and (vi) being able to read and write Arabic. ${ }^{100}$ These naturalisation criteria are quite lax compared to other countries of the Middle East and North Africa. ${ }^{101}$ However, Syrian naturalisation rules draw distinction between citizens of Arab countries and citizens of non-Arab countries. Overall, Syrian legislation distinguishes three categories of populations: Syrians, Arabs and other foreigners. The differences between Arabs and non-Arabs in naturalisation procedures are listed in Chapter 6 of the Syrian Nationality Law under the section 'special provisions for other Arab nationals'. Article 6(3) states that the Minister of Interior can, at their discretion, waive regular conditions when the applicant is 'of Arab origin' and able to provide 'a good reason' for

93 Stewart Reiser, 'Pan-Arabism Revisited' (1983) 37(2) Middle East Journal 218.

94 Ma'oz Zeev, 'The Evolution of Syrian Power, 1948-1984' in Ma'oz Moshe and Avner Yaniv (eds), Syria Under Assad (Croom Helm 1986) 68, 72-78.

95 Syrian Nationality Law (n 2).

96 Idriss Jebari, 'The Rise and Fall of the Arab Left' in Francesco Cavatorta, Lise Storm, Valeria Resta (eds), The Routledge Handbook on Political Parties in the Middle East and North Africa (Routledge 2020) 1.

97 Constitution of the Syrian Arab Republic 1973 (no longer in force), superseded by the Constitution of the Syrian Arab Republic 2012. The English version has been translated by the International Labour Organization: 'Constitution of the Syrian Arab Republic', International Labour Organization (Web Page) $<$ https://www.ilo.org/dyn/natlex/docs/ELECTRONIC/91436/106031/F931434246/constitution2.pdf>.

98 Constitution of the Syrian Arab Republic 2012 preamble [1], art 1 (emphasis added).

99 Constitution of the Syrian Arab Republic 1973 (no longer in force) preamble [1] (emphasis added).

100 Syrian Nationality Law (n 2) art 4(1)(f).

101 Albarazi (n 10) 10. 
naturalisation. ${ }^{102}$ At first glance, this provision raises serious concerns vis-à-vis the prohibition of discrimination in international law. Syria is a mosaic of diverse religions and ethnicities, including Alawites, Armenians, Assyrians, Chechens, Druze, Ismailis, Kurds and others. ${ }^{103}$ Syria has historically been a country of refuge for people fleeing neighbouring countries, regardless of their ethnicities or country of origin. ${ }^{104}$ Pan-Arabism is a political movement that goes beyond identity-based claims, and is framed around ideas of fraternity, shared heritage and common values. ${ }^{105}$

Therefore, specific provisions in Syrian nationality law that favour 'citizens of Arab origin' need to be understood and analysed through an anti-colonial lens. Whilst certain provisions of Syrian legislation on nationality might appear as a form of ethnic discrimination at first, it actually stems from an anti-colonial movement that stroke for self-determination and ideals of equality. One must keep in mind that current nationality rules and borders in the Middle East are based on bogus colonial imaginaries, designed by former imperial powers, that do not reflect the identities of native populations. In that context, Pan-Arabism was initially conceived of as a resistance movement against colonial powers, revolving around the ideal of unity, not ethnic-based discrimination. It was a post-colonial effort to restore the existence of a democratic and independent Arab state aforementioned, which briefly existed under the rule of King Faisal in 1921. In fact, the declaration of independence issued by the Syrian Congress proclaimed a bill of rights, which included freedom of religion, freedom of press and equal citizenship for all residents of Syria. ${ }^{106}$ Thereafter, Pan-Arabism precisely aimed at restoring the sovereignty of Syrians, which was brutally crushed by European colonial powers. Equally, citizenship rules framed around Pan-Arabism aimed at unifying the citizens of Arabic-speaking countries who had suffered colonial decisions - regardless of their ethnicities or religious affiliation. As Fanon highlights, an important aspect of the anticolonial struggle is the unification of the natives under a common identity. ${ }^{107}$ Similarly to Pan-Arabism, Pan-Africanism is an anti-colonial movement that advocates for the reunification of all African territories. ${ }^{108}$ There were no borders in Africa before European colonial powers colonised the continent and divided it among themselves in the Berlin Conference. ${ }^{109}$ Pan-Africanism is an ideal that aimed at rectifying the devasting politics of division and separation enacted during colonial rule. Whilst this movement has never led to the creation of a unified African State, it encouraged and strengthened cooperation among sovereign nations. Overall, an anti-colonial analysis of Syrian citizenship reveals that certain forms of discrimination in Syrian naturalisation rules are the result of anti-colonial movements and resistance.

102 Syrian Nationality Law (n 2) art 6(3).

103 Joshua Castellino and Kathleen A Cavanaugh, Minority Rights in the Middle East (Oxford University Press 2013) 261.

104 Albarazi (n 10) 10.

105 Thompson, Colonial Citizens (n 10) 21.

106 Thompson, How the West Stole Democracy (n 16) 243.

107 Frantz Fanon, The Wretched of the Earth (Penguin 2001) 100-1.

108 Mark Malisa and Phillippa Nhengeze, 'Pan-Africanism: A Quest for Liberation and the Pursuit of a United Africa' (2018) 2(3) Genealogy 28.

109 Berlin Conference, 15 November 1884 - 26 February 1885. See Ieuan Griffiths, 'The Scramble for Africa: Inherited Political Boundaries' (1986) 152(2) Geographical Journal 204. 


\section{GENDER-BASED RULES IN SyRIAN NATIONALITY LAW}

\section{A The Introduction of Gender-Based Discrimination by the French Colonial}

\section{Administration}

As mentioned in the introduction, Syrian citizenship is principally based on art 3 of the Syrian Nationality Law, which provides that 'anyone born inside or outside the country to a Syrian Arab father ... shall be considered as Syrian Arab ipso facto'. ${ }^{110}$ This provision is the direct result of a patriarchal law introduced by the French colonial administration. ${ }^{111}$ From August 1924 to January 1925, the French High Commissioner ${ }^{112}$ issued a series of arrêtés ${ }^{113}$ laying down the legal framework on the transmission and acquisition of Syrian nationality. ${ }^{114}$ This patriarchal framework, directly inspired by French law itself, ${ }^{115}$ established the principle of paternal jus sanguinis, ${ }^{116}$ and made the acquisition of a woman's nationality dependent on her husband's. ${ }^{117}$ France also exported the principle of 'dependent nationality', whereby a woman loses her nationality if she marries a foreigner. ${ }^{118}$ Until 1973, French nationality law was based upon the principle of patria potestas — 'power of the father' — under which a woman was subjected to her husband's power. ${ }^{119}$ The introduction of this law represented a major step back for Syrian women who, under the Ottoman rule, enjoyed the right to pass on their nationality to their children on an equal basis with men. ${ }^{120}$ This historical fact challenges colonial and Orientalist discourses that blame patriarchal laws in the Middle East on a 'barbaric culture' or 'backward religion'. On the contrary, this discriminatory legislation is the pure product of so-called European civilisation, which ostensibly claims to be superior.

In this regard, it must be stressed out that the principle of paternal jus sanguinis was introduced by the French colonial administration following the transposition of the 1804 French Civil Code ('Napoleonic Code') into Syrian law. ${ }^{121}$ This code,

110 Syrian Nationality Law (n 2) art 3.

111 Parolin Gianluca, Citizenship in the Arab World: Kin, Religion and Nation-State (Amsterdam University Press 2009); Joseph M Haddad, The Syrian Nationality (American University of Beirut 1942).

112 The 'French High Commissioner' refers to the executive power during the Mandate.

113 In this context, the word 'arrêté' refers to a legislation unilaterally issued by the French administration during the colonial period.

114 Arrêté 2825 bis du 3 Août 1924 [Decree 2825 bis of 3 August 1924] 8(287) El Acima 1, 1 (State of Syria); Arrêté 16/S of 5 January 1925 (State of Syria), reproduced in Youssef S Takla, 'Corpus juris du mandat français' in Nadine Méouchy and Peter Sluglett (eds), The British and French Mandates in Comparative Perspectives/Les mandats français et anglais dans une perspective comparative (Brill 2003) 63, 97-98.

115 Mida R Zantout, 'Robbed of Citizenship: French Law Stripped Lebanese Women of Basic Rights They Freely Enjoyed under Ottoman Rule', Daily Star (online, 7 August 2008) $<$ https://www.dailystar.com.lb/News/Lebanon-News/2008/Aug-07/50815-robbed-ofcitizenship-french-law-stripped-lebanese-women-of-basic-rights-they-freely-enjoyedunder.ash $\mathrm{x}>$.

116 Arrêté 16/S (n 114) art 1.

117 ibid art 5: 'the foreign woman who marries a Syrian becomes Syrian' (tr author).

118 Code Civil 1804, art 18 (France) (no longer in force) ('Napoleonic Code').

119 Erwin Spiro, Law of Parent and Child (2 ${ }^{\text {nd }}$ ed, Juta \& Co 1985).

120 Law No 19 of 1869 'Nationality Law' (Ottoman Empire), cited in Will Hanley 'What Ottoman Nationality Was and Was Not' (2016) 3(2) Journal of the Ottoman and Turkish Studies Association 277.

121 Napoleonic Code (n 118), also known as 'Code Napoléon' in French. 
which represented the core of French civil law, was a compilation of patriarchal rules that subjected women to legal incapacity. Under this code, women were forced by law to obey their husbands, ${ }^{122}$ prohibited from securing their rights before Courts ${ }^{123}$ and unable to buy, give or sell their own goods without their husband's approval. ${ }^{124}$ In short, French law viewed women as having the same legal capacity as criminals and children. One of the most fierce and misogynist provision of the Napoleonic Code was the 'rape marriage law', an article according to which a man who kidnapped or raped a girl could avoid prison by marrying his victim. ${ }^{125}$ This law, and the Napoleonic Code more generally, was exported by France in all its colonies, including in Lebanon, ${ }^{126}$ Morocco, ${ }^{127}$ Algeria ${ }^{128}$ and Tunisia. ${ }^{129}$ Although the Code was largely regarded as a symbol of progress and modernisation in Europe, ${ }^{130}$ it represented a major step backwards for non-Western women. Before the Anglo-French occupation, Ottoman women enjoyed the right to sign binding contracts, to buy or sell goods without their husband's permission and to secure their legal rights in court on their own behalf. ${ }^{131}$

In fact, Turkish women obtained the right to vote in 1930, 14 years before French women did. ${ }^{132}$ Therefore, it is a colonial fallacy to maintain that European colonialism somehow brought 'civilisation' or enhanced gender equality of local populations. ${ }^{133}$ It actually had the opposite effect. This provision further illustrates how patriarchy is an inextricable part of the racism and brutality of colonialism. Although the oppressive colonial machinery was aimed at subjugating all native populations, ${ }^{134}$ it had a disproportionate impact on women. It seems like the socalled 'civilising mission' put forward by the French was subjugating women, rather than about bringing civilisation. In this regard, it must be stressed that Britain introduced the same gender-based discrimination in its colonies, including in Jordan, Iraq and India, following a similar pattern. ${ }^{135}$ Both colonial powers are therefore responsible for introducing this patriarchal principle, and yet the

122 ibid art 213.

123 ibid arts 215, 221, 1124.

124 Hanley (n 120).

125 Rothna Begum, 'Middle East on a Roll to Repeal "Marry the Rapist" Laws', Human Rights Watch (online, 24 August 2017) <https://www.hrw.org/news/2017/08/24/middle-east-rollrepeal-marry-rapist-laws $>$.

126 Legislative Decree No 340 'Penal Code' (1943) art 522 (Lebanon). Article repealed in August 2017. 'Lebanon Rape Law: Parliament Abolishes Marriage Loophole', BBC News (online, 16 August 2017) <https://www.bbc.co.uk/news/world-middle-east-40947448>.

127 Dahir No 1-59-413 'Code Penal' (1962) 28 Joumada II 1382, art 475 (Morocco). Article repealed by Loi No 1-14-06 (2014) 18 Bulletin Officiel 2492.

128 Ordonnance No 66-156 du 8 juin 1966 portant code penal (2011) art 308 (Algeria). Article repealed in 2017.

129 Code Penal (1913) art 227 bis (Tunisia) (no longer in force). Article repealed in 2016.

130 In Europe, the Napoleonic Code (n 118) was actually regarded as a symbol of modernisation and progress. See Xavier Martin, Fonction paternelle et Code Napoléon (Annales Historiques De La Révolution Française, 1996) 466.

131 Zantout (n 115) 2.

132 Valentine Moghadam, Modernizing Women: Gender and Social Change in the Middle East (Lynne Rienner Publishers 1993) 91.

133 Deniz Kandivoti, Gendering the Middle East: Emerging Perspectives (Syracuse University Press 1996).

134 Fanon (n 107); Memni (n 72).

135 Radha Govil and Alice Edwards, 'Women, Nationality and Statelessness' in Alice Edwards and Laura Van Waas (eds), Nationality and Statelessness under International Law (Cambridge University Press 2014) 169. 
majority of the Western academic literature fails to mention this colonial heritage and present gender inequality laws in Syria as a result of religious tradition or cultural 'backwardness'. ${ }^{136}$ The patria potestas principle introduced by France is translated in art 30 of the current Syrian Nationality Law, which provides that 'a minor shall have their father's nationality'. ${ }^{137}$ This patriarchal rule also means that only Syrian men can pass on their citizenship to their spouse. ${ }^{138}$ Consequently, this example illustrates how citizenship regulation and statelessness can be the expression of both patriarchy ${ }^{139}$ and colonialism. ${ }^{140}$ The introduction of patriarchal provisions within nationality legislation is one of the major causes of statelessness in Syria.

\section{B The Impact of Gender-Based Discrimination on Statelessness}

Gender-based discrimination in nationality rules has been identified as one of the main causes of statelessness. ${ }^{141}$ Paternal jus sanguinis can lead to statelessness in situations whereby the father is stateless, unknown, has died before registering the child or simply refuses to recognise the child. In order to prevent such a situation, art 3 of the Syrian Nationality Law allows the acquisition of nationality to: 'anyone born in the country to a Syrian Arab mother and whose legal family relationship to his father has not been established' ${ }^{142}$ Nonetheless, this provision fails to tackle statelessness properly because it only concerns children born within the country and therefore excludes the ones born in exile. It furthermore refers to the status of the father instead of focusing on the risk of statelessness the child faces per se. As a result, art 3 is rarely implemented in practice ${ }^{143}$ because children born to unknown fathers face a series of bureaucratic barriers and social obstacles. ${ }^{144}$ Notably, there is a strong social stigma surrounding children born out of wedlock $^{145}$ or within terrorist organisations. ${ }^{146}$ Gender-biased laws are 'particularly hard on less-educated women, frequently from rural [areas], who married foreigners and had no resources for tracking the father or pursuing nationality claims for their children'. ${ }^{147}$ On the other hand, communities from

136 Zantout (n 115) 9.

137 Syrian Nationality Law (n 2) art 30.

138 ibid art 18.

139 Deirdre Brennan, 'Statelessness and the Feminist Toolbox: Another Man-Made Problem with a Feminist Solution?' (2019) 24(2) Tilburg Law Review 170.

140 Hilary Charlesworth, Christine Chinkin and Shelley Wright, 'Feminist Approaches to International Law' (1991) 85(4) The American Journal of International Law 613.

141 Zahra Albarazi and Laura van Waas, 'Towards the Abolition of Gender Discrimination in Nationality Laws' [2014] 46 Forced Migration Review 49; Neda Shaheen, 'Discriminatory Nationality Laws Must Be Eliminated in Order to Eradicate Statelessness' (2018) 11(2) DePaul Journal for Social Justice 1.

142 Syrian Nationality Law (n 2) art 3(b), (c), (d), (e).

143 Laura van Waas and Zahra Albarazi, 'Transformations of Nationality Legislation in North Africa' in Engin F Isin and Peter Nyers (eds), Routledge Handbook of Global Citizenship (Routledge 2014) 208.

144 Albarazi (n 10) 23.

145 Nationality and Causes of Statelessness in the Middle East and North Africa Report (Report, The Legal Agenda 2016) <https://english.legal-agenda.com/nationality-and-cases-ofstatelessness-in-the-middle-east-and-north-africa/> ('Legal Agenda Report 2016').

146 Betsy Fisher, 'Why Non-Martial Children in the MENA Region Face a Risk of Statelessness', Harvard Human Rights Journal (online, 2015) <https://harvardhrj.com/2015/01/why-nonmarital-children-in-the-mena-region-face-a-risk-of-statelessness/>.

147 Khadija Elmadmad, 'Les réfugiés et les apatrides au Maroc: des étrangers pas comme les autres' [2011] Numéro Spécial de la Revue de l'Université Moulay Ismail à Meknès 67. 
privileged, upper-class and educated backgrounds are more likely to overcome the social and bureaucratic obstacles aforementioned. ${ }^{148}$ Overall, the fact that statelessness is still perpetuated from generation to generation in Syria demonstrates how inefficient art 3 really is in preventing and eradicating statelessness. ${ }^{149}$

In addition, the mass displacement of populations coupled with political instability and insecurity created by the 2011 civil war has dramatically increased the risk of statelessness in two ways. Firstly, many fathers have died, disappeared or simply abandoned their children during the war, making it more difficult to prove the paternal lineage to a Syrian father. UNHCR estimates that one-fourth of Syrian refugee households are led by women, ${ }^{150}$ and that over 300,000 Syrian children were born in exile between 2011 and 2016. ${ }^{151}$ Access to birth registration is primordial for Syrian children born outside the country because it provides evidence of their identity, their family links, and, as a result, their right to Syrian citizenship. According to the Convention on the Rights of the Child, which Syria is a state party to, 'each child shall be registered immediately after birth and shall have the right from birth to a name [and] the right to acquire a nationality'. ${ }^{152}$ Yet, the ongoing conflict makes it hard for Syrian families to register their childbirth, especially when the father is absent. Particularly, many Syrians living abroad are not aware of the necessity of registering their child at the nearest consulate, ${ }^{153}$ or had their identity documentation lost, stolen or destroyed during the war. ${ }^{154}$ In rebel-held areas, civil registration systems have not operated for years, leading to the impossibility of registering marriages, births and deaths - all of which can prevent access to nationality. ${ }^{155}$ As of July 2020, around 4.1 million Syrians were living in non-governmental controlled areas. ${ }^{156}$ In addition of the widespread loss of documentation in rebel-held territories, the validity of identity documents issued by non-state actors is disputed. All of these factors make it significantly challenging to prove Syrian citizenship, leading to a rise in the numbers of Syrians deprived of their right to nationality. Whilst the outbreak of the civil war coupled with gender-based discrimination has heightened the risk of statelessness, it is undoubtfully not a new phenomenon in Syria. Mass cases of statelessness existed before the conflict, especially among Kurds and Palestinians who have been deprived of nationality by colonialism.

148 Legal Agenda Report 2016 (n 145).

149 Statelessness in Syria: Country Position Paper - August 2019 (Report, European Network on Statelessness and Institute on Statelessness and Inclusion 2019) $<$ https://statelessjourneys.org/wp-content/uploads/StatelessJourneys-Syria-August2019.pdf> ('Statelessness in Syria')

150 Woman Alone (n 3).

151 In Search of Solutions: Addressing Statelessness in the Middle East and North Africa (Report, UNHCR September 2016) <https://www.refworld.org/docid/57dbdaba4.html > ('In Search of Solutions').

152 Convention on the Rights of the Child, opened for signature 20 November 1989, 1577 UNTS 3 (entered into force 2 September 1990) art 7 ('CRC'). This is the most widely-ratified international human rights treaty in history. The United States is the only country in the world that has not ratified the $C R C$.

153 In Search of Solutions (n 143).

154 Action 7: Ensuring Birth Registration for the Prevention of Statelessness (Good Practices Paper, UNHCR 2017) <https://www.refworld.org/pdfid/5a0ac8f94.pdf>.

155 ibid.

156 Syrian Arab Republic: Recent Developments in Northwest Syria Situation (Report No 18, United Nations Office for the Coordination of Humanitarian Affairs 25 July 2020) $<$ https://reliefweb.int/sites/reliefweb.int/files/resources/nw_syria_sitrep18_25july2020.pdf $>$. 


\section{The Deprivation of the Right to SELF-Determination FOR the KuRDS}

\section{AND PALESTINIANS}

Colonial policies have deprived both Kurds and Palestinians of their right to selfdetermination, leaving them stateless and vulnerable to forced expulsion. Prior to the outbreak of the Syrian civil war, around 300,000 Kurds and more than 550,000 Palestinian refugees living in Syria were de jure stateless. ${ }^{157}$ Although Kurds and Palestinians are both 'a people without a country', ${ }^{158}$ their legal status in Syrian legislation differs significantly. This section proceeds to analyse the responsibility of colonialism in creating statelessness among Palestinians and Kurds, and their legal status in Syrian citizenship.

\section{A British Support for Zionism and the Creation of Statelessness among}

\section{Palestinians}

The roots of the Palestinian refugee problem are to be found in British colonial policies. After Britain entered and occupied Palestine, under the legal approval of the League of Nations, colonial authorities began organising and facilitating the mass immigration of Jews from Europe, in an effort to fulfil the Zionist political project. ${ }^{159}$ Britain promised in the 1917 Balfour Declaration to create a Jewish state in Palestine, ${ }^{160}$ without consulting native populations. In 1947, the United Nations presented a partition plan to create a Zionist State in Palestine, which would allocate only $45 \%$ of the land to Palestinians although they owed $93 \%$ of it. 161 Native Palestinians and Arab neighbouring states strongly rejected this proposal, which they saw as a continuity of colonialism, and a war broke out as a result. ${ }^{162}$ The new state of Israel, militarily and politically supported by Britain and France, won the 1947-48 conflict and forcibly expelled 750,000 Palestinians from their homes - which represented around $85 \%$ of the indigenous population of former British Mandate Palestine. ${ }^{163}$ The majority of them were internally displaced or sought refuge in the neighbouring countries of Lebanon, Jordan, Syria and Iraq. ${ }^{164}$ This event is known in the Palestinian consciousness as the 'Nakba' - literally 'catastrophe' in Arabic - and marked the beginning of their forced exile and statelessness that still remains unresolved to this day. ${ }^{165}$ It also marked the beginning of the dispersal of the Palestinian community and their political

157 McGee (n 5).

158 Gerard Chaliand, People without a Country: The Kurds and Kurdistan (Zed Press 1982).

159 Alexander Scholch, 'Britain in Palestine, 1838-1882: The Roots of the Balfour Policy' (1992) 22(1) Journal of Palestine Studies 39.

160 Walid Khalid, 'The Hebrew Reconquista of Palestine: From the 1947 United Nations Partition Resolution to the First Zionist Congress of 1897' (2009) 39(1) Journal of Palestine Studies 24.

161 Avi Shlaim, 'By Recognising Palestine, Britain Can Help Right the Wrongs of the Balfour Declaration', Balfour Project (online, 2020) <https://balfourproject.org/right-the-wrongs/>.

162 Michael E Dumper, Palestinian Refugee Repatriation: Global Perspectives (Routledge 2006) 2.

163 Francesca Albanese and Lex Takkenberg, The Status of Palestinian Refugees in International Law (Oxford University Press 2020).

164 ibid.

165 Ahmad H Sa'di, 'Catastrophe, Memory and Identity: Al-Nakbah as a Component of Palestinian Identity’ (2002) 7(2) Israel Studies 175. 
struggle for self-determination. ${ }^{166}$ Around half a million Palestinians sought refuge in Syria during the Nakba. The 1967 Arab-Israeli war has further led to the displacement of more than 300,000 Palestinians. ${ }^{167}$ Moreover, Israeli is illegally occupying the Syrian Golan Heights, a territory populated by around 25,000 Syrian Druze. The vast majority of them are stateless because they strongly reject Israeli citizenship, and still hope to rejoin Syria one day. ${ }^{168}$ The creation and existence of the state of Israel is the continuation of European colonialism in a vacuum, not just because of the Balfour Declaration, but also through the ongoing settler-colonialism and a visible remnant of hegemony. ${ }^{169}$ The creation of the state of Israel was motivated by racial hierarchies and colonial ideas, as illustrated by the following quote of Winston Churchill addressing Palestinians in 1937:

I do not admit ... that a great wrong has been done to the red Indians of America or the black people of Australia. I do not admit that a wrong has been done to these people by the fact that a stronger race, a higher-grade race, a more worldly-wise race to put it that way, has come in and taken their place. 170

Therefore, Britain denied sovereignty to Palestinian people not because of a historical mistake, but because they saw native populations as an inferior race undeserving of human rights. Colonial policies enacted by Britain are responsible for engendering the mass displacement, ongoing statelessness, and enduring suffering of the Palestinian people.

\section{B The Legal Status of Palestinians in Syrian Nationality Law}

Before the outbreak of the Syrian conflict, there were approximately 1 million Palestinian refugees living in Syria — from which 560,000 were officially registered. ${ }^{171}$ Pursuant to Syrian legislation, Palestinians enjoy equal rights regarding 'employment, work, business and military service without prejudice to their original nationality'. ${ }^{172}$ In addition to economic rights, Palestinians are entitled to free secondary education and equal access to Syrian universities. ${ }^{173} \mathrm{In}$ terms of mobility, they enjoy the same rights as Syrian nationals: they are entitled to travel documents, that can be obtained or extended via any Syrian embassy abroad, which allow them to re-enter Syria and take up residence there - no

166 Albanese and Takkenberg (n 163) 35.

167 Janet L Abu-Lughod, 'Palestinians: Exiles at Home and Abroad' (1988) 36(2) Current Sociology 63.

168 Maria A Kastrinou, Salman Fakher El-Deen and Steven B Emery, 'The Stateless (Ad)vantage? Resistance, Land and Rootedness in the Israeli-Occupied Syrian Golan Heights', Territory, Politics, Governance (online, 2020) 1 $<$ https://www.tandfonline.com/doi/full/10.1080/21622671.2020.1743203>.

169 Magid Shihade, 'Settler Colonialism and Conflict: The Israeli State and Its Palestinian Subjects' (2012) 2(1) Settler Colonial Studies 108; David Lloyd, 'Settler Colonialism and the State of Exception: The Example of Palestine/Israel' (2012) 2(1) Settler Colonial Studies 59; Ronit Lentin, 'Race and Surveillance in the Settler Colony: The Case of Israeli Rule over Palestine' (2017) 3(1) Palgrave Communications 1.

170 Shlaim (n 161).

171 UN Human Rights Council, Working Group on the Universal Periodic Review, National Report of the Syrian Arab Republic, UN Doc A/HRC/WG.6/26/SYR/1 (28 September 2016) [15] <https://undocs.org/en/A/HRC/WG.6/26/SYR/1>.

172 Law No 260 of 10 July 1957, art 1 (Syrian Arab Republic), reproduced in Davis (n 79) 39.

173 Laura Anne Reeds, 'Sixty Years in Limbo: The Duty of Host States to Integrate Palestinian Refugees under Customary International Law’ (2006) 81(1) New York University Law Review 375 . 
matter the length of time they might have spent abroad. ${ }^{174}$ They can also access social benefits provided by the Syrian government on a par with citizens. ${ }^{175}$ According to Reeds, 'Palestinian refugees in Syria enjoy equality with Syrian citizens in most aspects of their lives and have achieved a significant degree of integration'. ${ }^{176}$ Nonetheless, Palestinians remain still excluded from political rights - such as voting or standing for in parliamentary elections - despite being required to perform the military service. ${ }^{177}$ This constitutes a legal anomaly, since military service normally goes hand-in-hand with citizenship. The Constitution of the Syrian Arab Republic itself refers to military service as a duty of all male citizens. ${ }^{178}$

Palestinians who have been living in Syria for seven decades and are treated on an equal basis with nationals remain excluded from the naturalisation process because of the 1965 Protocol for the Treatment of Palestinians in Arab States, also known as the 'Casablanca Protocol'. ${ }^{179}$ The Protocol, adopted by the LAS, regulates the rights and obligations of Palestinian refugees living in Arabicspeaking countries. ${ }^{180}$ According to this instrument, host Arab states are bound to treat Palestinians on an equal basis with non-nationals and ensure their legal status is fully secured. ${ }^{181}$ That includes equal economic rights, ${ }^{182}$ the right to leave and return to the state they are residing in ${ }^{183}$ and equal rights with citizens regarding visas and residency. ${ }^{184}$ State-parties are also required to issue refugee travel documents to allow Palestinians to move across borders whilst maintaining their refugee status. ${ }^{185}$ Overall, this treaty is based on a rights-based approach that ensures Palestinians are treated on an equal basis with citizens. However, one major controversial feature of the treaty is the opposition to naturalisation: [3] of the Protocol's preamble states that Palestinians shall not be granted the nationality of the host state in order to preserve their 'national identity'. ${ }^{186}$ This provision was introduced on the ground that naturalisation would undermine the Palestinians' right of return to their ancestral lands, a right enhanced in UN resolutions. ${ }^{187}$

Yet, this view does not find any support in international law nor history. Naturalisation of refugees in the host state has never been incompatible with the right of return. Still, the LAS decided to enact this provision in 1965, in the hope that Palestinians would, one day, be able to return. The current political context shows little probability for the realisation of this right. Palestinian refugees remain,

174 Law No 1311 of 1963, art 8 (Syrian Arab Republic), cited in Asem Khalil, 'Palestinian Nationality and Citizenship: Current Challenges and Future Perspectives' (Report No 2007/7, European University Institute Robert Schuman Centre for Advanced Studies 2007).

175 ibid art 1.

176 Reeds (n 173) 374.

177 ibid.

178 Constitution of the Syrian Arab Republic 2012, 46.

179 League of Arab States, Protocol for the Treatment of Palestinians in Arab States (Casablanca Protocol), opened for signature 11 September 1965 ('Casablanca Protocol').

180 Albanese and Takkenberg (n 163) 188.

181 ibid.

182 Casablanca Protocol (n 179) art 1.

183 ibid art 2.

184 ibid art 5.

185 ibid arts $3,4$.

186 ibid preamble [3]: 'Whilst retaining their Palestinian nationality'.

187 Palestine - Progress Report of the United Nations Mediator, UNGA, UN Doc A/RES/194(III) (11 December 1948); Question of Palestine, UNGA, UN Doc 3236(XXIX) (22 November 1974). 
nonetheless, excluded from naturalisation in host Arab countries - including in Syria. Their identity documents are not equivalent to a citizenship and Palestinians remain de jure stateless. This situation of legal insecurity has been further exacerbated by the Syrian conflict. Before the war broke out, Syria hosted two main Palestinian refugee camps: (i) Yarmouk camp located near Damascus where approximately 160,000 Palestinian refugees were living; and (ii) De'raa camp in southern Syria was home to 10,000 people. Both refugee camps have been the scene of violent unrest and fights between Syrian authorities and armed groups. ${ }^{188}$ There are now only 1,000 people left in Yarmouk, and less than 400 families in De'raa. ${ }^{189}$ Palestinians from Syria who fled to neighbouring countries are particularly vulnerable because of their exclusion from Syrian citizenship. The legal situation of the Kurdish community of Syria is even more precarious, as the next sub-Part elucidates.

\section{Kurdish Syrians: When Ethnic Identities Meet Stateless Identities}

With an estimated number of 35 million people, the Kurdish community is referred to as 'the largest stateless nation in the world'. ${ }^{190}$ Similar to the Palestinians, they are united through ethnicity, culture, history and language - although they do not share a common dialect. ${ }^{191}$ They used to have their own independent state, in the form of a kingdom, before the invasion by the Ottomans in the $13^{\text {th }}$ century. ${ }^{192}$ And, again, like the Palestinians, the dislocation of the Ottoman Empire by victorious European powers left them with no land. They ended up divided among the four modern states of Turkey, Iran, Iraq and Syria. ${ }^{193}$ It is estimated that the Kurds in Syria represent about $10 \%$ of the total Syrian population. ${ }^{194}$

On 5 October 1962, Syrian authorities enacted a census in the Kurdishpopulated governorate of Al-Hasaka in northern Syria. ${ }^{195}$ The former Syrian Government ${ }^{196}$ argued that, from 1945 onwards, many migrants crossed the Turkish-Syrian border irregularly and established themselves in Syria by using falsified identity documents. ${ }^{197}$ According to this point of view, the 1962 census committee was conducted to identify these migrants and at repealing the Syrian nationality they supposedly obtained fraudulently. ${ }^{198}$ Syrian authorities provided less than 24 hours to the inhabitants of the province of Al-Hasaka to provide documents proving their lawful residency prior to 1945. The outcome of the 1962 census led to the identification of three categories of population:

188 'Almost All UNRWA Installations in Yarmouk and Dera'a Camp in Syria Severely Damaged or Destroyed', United Nations Relief and Works Agency (online, 1 December 2018) $<$ https://bit.ly/2TuPITj>.

189 Statelessness in Syria (n 149).

190 Kerim Yildiz, The Kurds in Syria: The Forgotten People (Palgrave Macmillan 2005) 12.

191 ibid 4.

192 ibid 18

193 Treaty of Sèvres (n 66).

194 Sean Lee, 'The Kurds of Syria' (2017) 25(2) Arab Studies Journal 226.

195 Legislative Decree No 93 (1962) (Syrian Arab Republic).

196 It must be noted that the current Syrian regime did not enact this census. The authorities in power at the time were a previous government that lasted less than five years. See Albarazi (n 72) 7.

197 Committee on the rights of the Child, Consideration of Report of States Parties (Continued): Initial Report on Syrian Arab Republic (Continued), CRC, UN Doc CRC/C/SR.361 (21

198 ibid. March 1997) 8. 
i. Those able to prove their residency prior to 1945 were recognised as Syrian nationals.

ii. Those who attempted to prove their residency by providing documentation but failed to convince Syrian authorities were classified as Ajnabi 'foreigners' in Arabic. They have been officially recorded in a civil register of foreigners and have been given a 'red card'. ${ }^{199}$ Holders of these cards are allowed 'leave to remain' in Syria but have no right to return if they leave the country for whatever reason.

iii. Those who did not have any documentation, were absent, or refused to take part in the census were deemed Maktoumeen - 'concealed' in Arabic. They are undocumented residents who are not even considered as foreigners. Their personal data was not registered in any official record and they are considered as residing unlawfully in Syria. ${ }^{200}$

Since both Ajnabi and Maktoumeen did not hold any other nationality than the Syrian one, they were consequently rendered stateless. As a result of this census, 120,000 Kurds - representing around $20 \%$ of the total Kurdish Syrian population - lost their citizenship. Although Syria is not a party to the 1954 and 1961 Statelessness Conventions, it has ratified many international human rights conventions that protect the right to a nationality and expressly prohibit deprivation of citizenship when it leads to statelessness. ${ }^{201}$ Moreover, there were significant inconsistencies and irregularities in the implementation of the 1962 census, making it a highly arbitrary process. ${ }^{202}$ First of all, it was carried out during a brief period of 24 hours only, which left no time to the inhabitants of the AlHasaka province to collect the necessary documents, or even to understand what was happening, and the process automatically excluded people who were not present on the relevant day. ${ }^{203}$ According to a Syrian lawyer, 'thousands of people went to sleep as Syrians and woke up to find that they no longer were [citizens]'. ${ }^{204}$ Because the census was carried out during one single day, testimonies argue that decisions of registration were rushed and deficient, and designed to deprive a large minority of their political weight in the new-born state. ${ }^{205}$ Furthermore, the decree only left three months to appeal the decision of revoking Syrian citizenship. ${ }^{206}$ Zahra Albarazi posits that, given the 'deficiency' of the government and of judicial institutions at the time, it was arduous to lodge an appeal and seek justice in any effective way. ${ }^{207}$ One Kurdish Syrian, deprived of his citizenship during the census explained how he tried to restore his citizenship by lodging numerous requests respectively in 1970, 1980 and 1988 before Syrian authorities. His demands were dismissed each time on the ground that 'he is from the people of Al-Hasaka governorate'. ${ }^{208}$ Therefore, this example illustrates how Syrian

199 ibid.

200 ibid.

201 That includes UDHR (n 6) art 15.

202 Albarazi (n 10) 8.

203 'Repression of Kurdish Political and Cultural Rights in Syria', Human Rights Watch (online, 26 November 2009) <https:/www.hrw.org/report/2009/11/26/group-denial/repressionkurdish-political-and-cultural-rights-syria> ('Repression in Syria').

ibid.

205 Albarazi (n 10) 10.

206 ibid.

207 Repression in Syria (n 203).

208 Manaa (n 62). 
citizenship is racialised, a legacy that can be traced back to the racialisation of communities during French colonial rule. ${ }^{209}$

The 1962 census deprived Kurdish communities of their political, economic and civil rights, and their everyday life became extremely difficult, particularly in terms of access to education and employment. ${ }^{210}$ They faced difficulty in registering their children at birth and sending them to school, and were banned from working in the public sector and benefit from ratio foods, which were reserved to Syrian citizens - because they were now considered 'foreigners'. Additionally, this census prevented them from travelling because of their lack of identity documentation. In the 1990s, Syrian authorities expelled stateless Kurds from their homes and arbitrarily seized their agricultural lands. ${ }^{211}$ Many who tried to peacefully protest against this decision were arrested and detained, and some were sentenced to up to four years imprisonment. ${ }^{212}$ Therefore, the 1962 census appears to be a political decision motivated by ethnic-based discrimination, rather than immigration concerns. The census left long-lasting marks that still have consequences to this day. In the early years of the Syrian conflict, many Kurdish Syrians were put in detention because of their inability to present identity documents at checkpoints. ${ }^{213}$ When fleeing Syria, they have also found themselves excluded from some resettlement programs available to other vulnerable refugees in neighbouring countries, because they could not prove their Syrian nationality. ${ }^{214}$

In 2011, the Syrian regime started to make concessions in an attempt to pacify the political tensions in the country, after the outbreak of popular uprisings across the country and shortly before the civil war officially began. ${ }^{215}$ A first decree allowed the Ajnabi to access social services ${ }^{216}$ and a second one stated that they should be treated on an equal basis with Syrian nationals in terms of employment. ${ }^{217}$ Finally, on 7 March 2011, President Bashar Al-Assad issued a decree that granted the Syrian nationality to all the Ajnabi living in the province of Al-Hasaka at that point - but not to all the Syrian Ajnabi that may have moved to other parts of the country since the census took place. ${ }^{218}$ Before the census, the Syrian regime had dismissed all demands calling for the naturalisation of stateless Kurds, arguing that naturalisation could only be made on an individual basis. ${ }^{219}$ Nonetheless, this decree was granted as a 'favour', rather than as the rectification of a legal breach committed through the defective census process. No compensation or reparation was offered. ${ }^{220}$ Many Kurds had fled Syria before

209 David Fitzgerald, 'The History of Racialized Citizenship' in Ayelet Shachar, Rainer Bauböck, Irene Bloemraad, and Maarten Vink (eds.) The Oxford Handbook of Citizenship (Oxford University Press 2017) 129.

210 Albarazi (n 10) 4.

211 Manaa (n 62).

212 ibid.

213 Thomas McGee and Zahra Albarazi, 'Eight Years of Displacement: Syria’s Statelessness Still Unidentified' (2019) 8(2) Oxford Monitor of Forced Migration 39, 40.

214 ibid.

215 Albarazi (n 10) 18.

216 Decree No 153/11 (2011) (Syrian Arab Republic).

217 ibid.

218 ibid art 1, which stipulates: 'Individuals who are registered as Ajnabi in the Al-Hasaka province should be granted the Syrian nationality' (emphasis added) (author tr).

219 ibid.

220 Albarazi (n 10) 12. 
having the opportunity to apply for citizenship under the decree. ${ }^{221}$ Moreover, the Maktoumeen remain stateless and the Syrian regime has made no call to resolve their situation. Overall, the 1961 census and the 2011 decree thus illustrate how states can manipulate nationality rules for political purposes. By stripping Kurds of their citizenship, the Syrian regime rendered their presence unlawful and made them feel like they do not 'belong'. Yet, Kurds have nowhere to seek refuge because the Anglo-French alliance broke their initial commitment to create a Kurdish independent state, and deprived Kurds off their right to self-determination as a result.

\section{ARBITRARY DENATIONALISATION IN SyRIAN LEGISLATION}

Denationalisation procedures were originally theorised and practiced in the United Kingdom and France, to be later exported all over Europe. ${ }^{222}$ They initially appeared in the $19^{\text {th }}$ century and were used as a form of punishment towards citizens who were considered 'unloyal' or 'dangerous'. Citizenship-stripping gradually disappeared because it was deemed incompatible with the nation-state system in which states reciprocally respected each other's right to control their borders and populations, and therefore the right to expel foreigners in their territory under certain circumstances. ${ }^{223}$ International law strictly prohibits deprivation of citizenship if it is arbitrary, unlawful, based on discriminatory grounds or when it leads to statelessness. ${ }^{224}$ However, citizenship-stripping has recently reappeared in Europe in the last decade, within the context of antiterrorism measures and the issue of 'foreign fighters' wishing to return back home. ${ }^{225}$

French colonial rule has introduced and significantly influenced Syrian legislation on de-nationalisation procedures. ${ }^{226}$ Article 21 of the Syrian Nationality Law lists several grounds on which Syrians might be stripped off their nationality. ${ }^{227}$ Those include 'citizens who reside in a non-Arab country for more than three years and who do not respond to requests for a justification of their absence within three months, or provide an insufficient response'. ${ }^{228}$ This provision does not define what constitutes sufficient justification or through which means it can be proven, leaving complete discretion to the Syrian authorities. It is a carte blanche for the stripping of Syrian nationality that can be strategically used against political opponents or against members of specific minorities, and there is no safeguard to which the individual can have recourse, such as the right of appeal. Article 21 has, effectively, being used for political purposes by the Syrian regime: in the 1960s and 1970s, President Hafez Al-Assad arbitrarily denationalised

221 Amit Sen, Lacking a Nationality, Some Refugees from Syria Face Acute Risks (Report, UNHCR 8 January 2014) <https://www.unhcr.org/hk/en/3810-lacking-a-nationality-somerefugees-from-syria-face-acute-risks.html>.

222 Mathew J Gibney, 'Banishment and the Pre-History of Legitimate Expulsion Power' (2019) 24(3) Citizenship Studies 277, 299.

223 ibid.

224 Syrian Nationality Law (n 2) art 21(g).

225 Dana Burchardt and Rishi Gulati, 'International Counter-Terrorism Regulation and Citizenship-Stripping Laws: Reinforcing Legal Exceptionalism' (2018) 23(2) Journal of Conflict and Security Law 203.

226 Thompson, Colonial Citizens (n 10).

227 Syrian Nationality Law (n 2) art 21.

228 ibid. 
27,000 political opponents - leaving them stateless. ${ }^{229}$ Children of political opponents are still forced to live in exile and denied Syrian citizenship. ${ }^{230}$

Historically, denationalisation policies have been largely used to target specific minorities who, despite possessing the citizenship of the country of residence, are considered as foreigners to the community. ${ }^{231}$ According to the United Nations High Commissioner for Refugees, more than $75 \%$ of the world's stateless population are from minority groups. ${ }^{232}$ It is on this basis that the Kurds of Syria were denationalised in 1962, with the stated purpose of identifying 'illegal migrants' clearly being a facade. ${ }^{233}$ In a response to a report from Human Rights Watch documenting the situation of stateless Kurds in Syria, ${ }^{234}$ Syrian authorities argued that, around 1945, many Kurds from Turkey had 'infiltrated' Syria. ${ }^{235}$ This dehumanising language reflects the disdain of Syrian authorities towards the Kurdish community. ${ }^{236}$ All successive Syrian governments have persecuted and discriminated the Kurds, both in the law and in practice. ${ }^{237}$ Indeed, history illustrates this strong link between ethnic-based discrimination and citizenship stripping. During World War I, Australia, for example, excluded Japanese citizens from naturalisation because they were considered as 'ethically undesirable'. ${ }^{238}$ In Nazi Germany and fascist Italy, denationalisation procedures were used against political opponents ${ }^{239}$ and as part of an ethnic cleansing process targeting homosexuals, the Jewish community and Roma people. ${ }^{240}$

Likewise, the recent resurgence of denationalisation procedures within in Europe has been criticised for targeting dual nationals, thereby creating a group of 'second-class citizens'. ${ }^{241}$ Overall, denationalisations practices in Syria should be read in conjunction with anticolonial history, rather than as a simple product of discrimination and arbitrariness. Citizenship stripping was theorised within Europe and introduced in Syria during colonial rule. Moreover, denationalisations practiced by European states have served as a model to the Syrian legislation, in an effort to target citizens deemed 'undeserving' of state protection.

229 Manaa (n 62).

230 ibid.

231 Audrey Macklin, 'The Return of Banishment: Do the New Denationalisation Policies Weaken Citizenship?' in Rainer Bauböck (ed), Debating Transformations of National Citizenship (Springer Cham 2018) 164.

232 'This Is Our Home': Stateless Minorities and Their Search for Citizenship (Report, UNHCR 2017) $<$ https://www.unhcr.org/ibelong/wpcontent/uploads/UNHCR_EN2_2017IBELONG_Report_ePub.pdf $>1$.

233 McGee and Albarazi (n 213) 32.

234 Syria: The Silenced Kurds (Report, Human Rights Watch October 1996) $<$ https://www.hrw.org/sites/default/files/reports/SYRIA96.pdf> ('The Silenced Kurds').

235 Committee on the Rights of the Child, Consideration of Reports Submitted by States Parties under Article 44 of the Convention - Concluding Observations: Syrian Arab Republic, CRC, UN Doc CRC/C/SYR/CO/3-4 (9 February 2012).

236 'Yatasalla'luna' in Arabic can be translated to 'they infiltrated'.

237 The Silenced Kurds (n 234).

238 Institute on Statelessness and Inclusion, 'Citizenship Stripping in the National Security Context: The Principles on Nationality Deprivation' (YouTube, 19 March 2020) $<\mathrm{https}$ ://www.youtube.com/watch?v=cv2znM9_fVk> ('Citizenship Stripping').

239 Philip W Bennett and Andreas Peglau, 'The Nazi Denaturalization of German Emigrants: The Case of Wilhelm Reich' (2014) German Studies Review.

240 Citizenship Stripping (n 238).

241 Laura van Waas and Sangita Jaghai-Bajulaiye, 'Stripped of Citizenship, Stripped of Dignity? A Critical Exploration of Nationality Deprivation as a Counter-Terrorism Measure' in Christophe Paulssen and Martin Scheinin (eds), Human Dignity and Human Security in Times of Terrorism (TMC Asser Press 2020). 


\section{CONCLUSION}

Western academic literature has traditionally identified contemporary causes of statelessness as principally stemming from discriminatory state policies and has largely ignored the legacies and heritage of colonialism in post-coloniality. This paper aimed to fill this research gap by demonstrating how, in the Syrian context, colonial legacies have played a decisive role in creating discrimination in nationality laws, which has resulted in mass statelessness. By relying on a TWAIL methodology that focuses on the historical formation of the law, this analysis has sought to uncover the hidden colonial legacies at the root causes of discrimination in Syrian citizenship and resulting cases of statelessness.

Firstly, this article has demonstrated how European colonial policies in the Middle East have created a mismatch between identity and nationality. The creation of artificial borders in the Sykes-Picot Agreements, motivated by the desire to divide colonised populations, is one of the roots of statelessness in modern Syria. This paper has, secondly, demonstrated how the dislocation of the Ottoman Empire by European colonial powers and the creation of artificial states has impacted upon the formation of new state citizenries and the emergence of stateless populations, including the Kurds and the Palestinians. Both communities were denied the right to self-sovereignty by colonial powers, on the basis of racialist hierarchies.

Thirdly, the transposition of gender-based discrimination by French colonial power during the occupation has created patriarchal citizenship rules that have increased the risk of statelessness. Gender inequality in Syrian citizenship is not the result of a backward culture or religion, but results from French colonial rule. In fact, this historical analysis has revealed that Syrian women enjoyed more rights regarding citizenship before French colonial rule. A similar provision, stripping women of their right to pass on their citizenship to their children, was introduced by British colonisers in other territories. Fourthly and finally, this paper ended by critically reflecting upon the arbitrary processes of naturalisation and denationalisation, largely inspired by Western practices. Overall, this analysis has challenged the idea that discriminatory practices in Syrian citizenship are the result of 'lawlessness' or an 'uncivilised' culture. It, rather, bears the legacy of the devasting impacts of European colonialism.

The present analysis has demonstrated that, far from bringing 'civilisation' or 'modernity', colonialism has brought nothing more than division, discrimination and stripped populations off their right to self-determination. Notably, genderbased discriminatory provisions in Syrian nationality law were introduced by the French colonial administration, stripping Syrian women of a right they previously enjoyed under Ottoman rule. As a result, current patriarchal laws cannot be attributed to the supposedly 'backwardness' and sexism inherent to Arab culture. Likewise, nationality provisions that favour Arab citizens were shaped by anticolonial struggles and cannot be read as a simple translation of ethnic-based discrimination. Overall, colonial legacies remain at the heart of current discrimination in Syrian nationality rules. Whilst it does not justify that the Syrian legislator is still maintaining such discrimination, it does offer a colonial explanation.

Beyond the Syrian case, this paper revealed the central role played by colonialism in creating statelessness and discrimination in citizenship. Mainstream narratives presuppose that statelessness is the result of current 
discriminatory practices adopted by modern states, largely neglecting the impact of colonialism. This paper demonstrated the shortcomings of such analysis, in failing to take into consideration the legacies of colonialism in creating mass statelessness. Citizenship and statelessness are not simply the expression of modern state power, but also reflect unequal power relations amongst states namely between the colonised and the coloniser. This component should not be neglected when analysing citizenship and statelessness in former colonies. A critical historical analysis of the formation of citizenship in former colonies can help revealing the role of colonialism in creating statelessness. 